\title{
A New Approach to Refugee's Welfare through the Role of Community: Case Study of Refugee's Community Centre in Sewon
}

\author{
A.A.I Diah Triceseria, Nurul Azizah Zayzda, \& Rizka Fiani Prabaningtyas \\ Universitas Gadjah Mada, Universitas Jenderal Sudirman, \& LIPI
}

\begin{abstract}
The role of state actor in refugee protection is seriously limited by the "nationalism" nature of a nation-state. In particular, there has been a lack of attention from Indonesia as implied by non-ratifying choice taken by the government. The problem here with this approach is, refugee's rights are viewed as entitlement from state and should conform with the state's interest. Thus, there needs to be a new approach in pursuing a refugee protection regime. This paper shifts the focus from the role of state to the roles played by other actors. This paper gives a particular focus on Refugee Community Housing in Sewon, Daerah Istimewa Yogyakarta. The Community Housing is an initiative from International Organization for Migration (IOM) which provides temporary settlement as well as living allowance for refugees. Our preliminary study found that the coordination among IOM, Jesuit Refugee Service (JRS)-an international NGO working to assist refugees, and Immigration Office of Yogyakarta-has to some extent demonstrated a better service and treatment to refugees than state's philanthropy in general. Some limitations remains exist, but overall, community housing provides a foundation for a civil society-based refugee protection.
\end{abstract}

Keywords: refugee, community housing, state

\begin{abstract}
Abstrak
Peran negara dalam perihal perlindungan pengungsi atau pencari suaka sangat terbatas karena konsep nasionalisme yang kental dalam sebuah negara-bangsa. Secara khusus, kurangnya perhatian Indonesia terhadap isu ini merupakan implikasi dari pilihan non-ratifikasi Konvensi Pencari Suaka oleh pemerintahannya. Permasalahan yang muncul dengan pendekatan ini adalah, hak pengungsi g dipandang sebagai hak yang diberikan oleh negara dan harus sesuai dengan kepentingan negara. Dengan demikian, perlu ada pendekatan baru dalam menjalankan sistem perlindungan pengungsi. Tulisan ini menawarkan pergeseran fokus dari peran negara ke peran yang dijalankan oleh aktor-aktor kemanusiaan lainnya. Fokus tulisan ini mengambil studi kasus perumahan komunitas pencari suaka (refugee community housing) Sewon, Daerah Istimewa Yogyakarta. Perumahan ini merupakan inisiatif dari International Organization of Migration (IOM) yang bertujuan untuk menyediakan pemukiman sementara serta biaya hidup bagi para pengungsi. Penelitian awal kami menemukan bahwa koordinasi antara IOM, Jesuit Refugee Service (JRS)— sebuah LSM internasional yang berkomitmen untuk bekerja dalam membantu pengungsi-dan Kantor Imigrasi Yogyakarta, merupakan retorika tentang pengungsi yang sampai batas tertentu menghargai hakhak mereka lebih dari filantropi negara. Beberapa keterbatasan tetap ada, tapi secara keseluruhan, perumahan komunitas ini memberikan dasar untuk perlindungan pengungsi berbasis masyarakat sipil.
\end{abstract}

Kata kunci: pengungsi, perumahan komunitas, negara 


\section{Background}

The issue of asylum seekers and refugees has been part of Indonesia's history since the first wave of refugees coming in 1979 as the result of Indo-Chinese Wars which caused more than 100.000 Vietnamese fled from their home country. Indonesia at that time provided assistance by accommodating them in Galang Island. This can be seen as the first policy taken by Indonesia's government in order to manage refugees. This policy was conducted under humanitarian motives, although there were also political motives behind it (Kusumaatmadja, 1983, p.33). After years, the phenomenon of international refugees and asylum seekers has received worldwide attention as the increasing number of international conflicts has concurrently raised the risk of people being persecuted.

In recent years, Indonesia has been facing another rising influx of asylum seekers and refugees. An article in Jakarta Post noted that the number of asylum seekers stranded in Indonesia according to UNHCR data in 2008 stood at only 385 people, but significantly rose to 3,230 people in the following year and still consistently increased until it reached 8,332 people in 2013. As of March 2014, there were 10,623 refugees and asylum seekers arriving in Indonesia (Jakarta Post, 2014) resulting partly from the implementation of strict immigration policies in Australia as one of the most popular destination countries for these refugees.

Learning from this increasing numbers of refugees in Indonesia, it is obvious that management for asylum seekers and refugees must be taken into serious consideration. Several efforts have indeed been made to adapt a system from the Refugee Protocol as seen in the draft of Presidential Decree which was based on Law No. 37/1999 on Foreign Relations. Yet still, this is insufficient legal bases to promotefor the welfare of refugees. Moreover, the government approach has dominantly seen refugees as illegal migrants who breach geographical borders without proper documentation. In addition, Indonesia as a non-signatory country has neither rights nor capacity to conduct Refugee Status Determination because this mechanism can only be done by UNHCR through their representative office. Seeing Indonesia as one of the most strategic entry point of refugees and asylum seekers to Australia, UNHCR then opens its office in Jakarta. Asylum seekers have to register themselves to UNHCR as the first step of many layers of bureaucracies to be entitled refugee status.

Considering this limited concern from Indonesian government to deal with refugee problems, this paper proposes to shift the focus of analysis from state actors to non-state actors in the case of Indonesia in order to yield a better understanding of this issue. It argues that the limitation of developing countries, such as Indonesia, to deal with refugees has given bigger room to non state actors who fill the gap through strategic cooperation not only with the state but also with other non-state actors. This paper would attempt to seek the possible solution on basic human rights fulfillment for refugees based on cooperation that have taken place in Indonesia between the Indonesian immigration office, IOM and JRS.

The discussion will begin with the overview of the limitation of Indonesian government in handling refugees and asylum seeker issues, followed with the role of nonstate actors in filling the gap resulted from this government's limitation. In order to do so, this research deploys qualitative approach through interviews, document reviews, and field observation. The depth of this research can be seen in its grasp on conceptual frameworks regarding the politics of refugees and role of non-state actors to endorse refugee's rights.

\section{Theoretical Perspective on the Role of States and Non-State Actors in Refugees Protection}

A work on rethinking the future of refugee protection regime was made by Helton (2002) outlining three "possible future directions" of refugee policy that are realistic to the present circumstances. They comprise of international cooperation, containment and proactive policy. However, all these three policies still rely too heavily on states' morality and have the tendency to end up as "charity" from the 
states for the refugees. By taking too much account of states' roles in refugee protection, our view will always be seriously limited by the 'national interest' which, when extended, represents the dilemmas in international refugee protection.

The obstacle imposed by the so-called "national interest" is a result of the taken-forgranted notion of sovereignty which becomes the foundation of nation-states system today. Benhabib's denotation is useful in understanding this:

Throughout the international system, as long as territorially bounded states are recognized as the sole legitimate units of negotiation and representation, a tension, and at times even a fatal contradiction, is palpable: the modern state system is caught between sovereignty and hospitality, between the prerogative to choose to be a party to cosmopolitan norms and human rights treaties, and the obligation to extend recognition of these human rights to all. (Benhabib, 2006, p. 31)

In the context of refugee protection, this results in continuing confusion of the refugee issue, and a huge gap between the hospitality principle and the implementation of international refugee law (Derrida, 2001, p. 11). This gap particularly lies on the point of departure in understanding refugee protection; whereas hospitality appreciates refugee protection as rights of refugees that is embedded in their existence, the sovereignty and citizenship system makes it an entitlement from the nation-states.

Nyers (2003) further emphasizes how the practice of globally accepted "refugee protection" is actually a political language to strengthen the notion of sovereignty.

In the case of asylum seekers, the decision over who will, and who will not, be provided with protection is not just a humanitarian determination, but a moment when the sovereign state (re)founds its claim to monopolize the political. (Nyers, 2003, p.1071)
This means, we need to be critical to the language policy of refugee protection by states worldwide. When a state formulates a refugee protection policy, it needs to be understood as a politics to legitimize its claims on human rights ${ }^{1}$, and on the other side, it reaffirms that protection is the right of the state to determine. The politics of refugees here is the process where power produces and reproduces the definition of refugee protection and their rights. This understanding of politics of refugees will help analysing the following sections, particularly on revealing the rhetoric of refugees produced by the state.

Due to the problematic politics of refugee by the state, it is a matter of urgency that we begin to learn refugee issue in a different perspectives. Glick-Schiller emphasizes the notion of a global power perspective, which sees migrants "not as foreigners to be differentiated from natives, but also as actors that connect local people to global process" (2010, p. 127). Through this global power perspective, it is possible to understand migrants' lives beyond the context of social cohesion, which is grounded on nationalism. Instead, it is possible to overlook the social solidarity, whether it is among the migrants or broader local community.

As the asylum seekers are part of the full picture of a global community, their struggle for recognition and entitlement needs to be scrutinized beyond an analysis of the top-down state's policy. In this sense, it is important to consider that policy can be made through support or challenge from "below" (Pero, 2011, p. 244). Considering that the limited power of asylum seekers in challenging a host-state's policy, support from civil society is crucial.

The actors who constitute civil society are the non-state actors, comprising of nongovernmental organizations (NGOs) and other civil organizations, which obtain the power to transform or challenge the policy through their activities (Pero, 2011, p. 244). These non-state actors establish a certain 
relationship with the government to address issues and interest of the public (Pero, 2007, p. 272).

The asylum politics here is pursued to empower the asylum seekers and refugees. To achieve that point, the civil society works by developing the capacity of the asylum seekers and refugees and supporting them through their set activities. The 'developmental role' of civil society in the governance of refugees has been categorized by Edwards (2009, p. 13) into social, economic and political aspects, as follows:

1. Economic: "securing livelihoods, providing services where states and markets are weak, nurturing social values, networks and institutions that underpin successful market economies, including trust corporation"

2. Social: "reservoir of caring, cultural life and intellectual innovation, teaching people the skill of citizenship and nurturing a collection of positive social norms that foster stability"

3. Political: "counterweight to states and corporate power and an essential pillar in promoting transparency, accountability and other aspects of "good-governance" the favorite term of foreign-aid donors in recent times" (Edwards, 2009, p. 13-15).

This paper focuses on elaborating how the civil-society based refugee protection is made possible by the roles of various actors. The coordination system between IOM, JRS, and local government could be a lesson learnt to determine whether the prevailing activities carried out by these actors have laid a foundation to foster the role of civil society. JRS as an NGO is part of civil society, but we are also take into account the neighboring community and the local NGOs.

The concept of developmental role by Edwards (2009) will be of use here to answer the research question about to what extent non-state actors have played their role in addressing asylum seekers and refugee issues in Indonesia, and how it works hand in hand with Indonesia's government within the existing condition. In the heart of this discussion is an understanding that the activities run by non-state actors influence the perspectives about refugee in Indonesia. Furthermore, the program of community housings does not solely provide services or facilities, they by all means push a transformation of the ways asylum seekers and refugees are accepted in Indonesia. The significance of this study in international relations study is found in its attempt to formulate the strategy in pursuing human rights of the refugees. Furthermore, through its analysis on the disclose of the politics of refugees, this research contributes to the debates about sovereignty and international protection of human rights.

\section{Analysis on State: Limitations and Ad- Hoc Protection by Indonesian Government}

The failure to legalize Presidential decree on asylum seekers and refugees simply means that there is no specific national policy designed to deal with such issues. The implication is clear, there are no official specific government bodies established for refugees and asylum seekers. In Indonesia, those two falls into the category of illegal immigrant issues under the Directorate General of Immigration and Ministry of Law and Human Rights. The absence of comprehensive national policy has affected on how state responds and allocates its resources to accommodate the asylum seekers and refugees.

UNHCR has referred to its cooperation with developing countries like Indonesia on refugees and asylum seekers issue as an adhoc protection cooperation. This simply means the arrangement was made for particular purpose only: due to the fact that Indonesia is a strategic transit area for asylum seekers who wants to go to Australia, UNHCR opens it office in Indonesia (Jakarta) to conduct refugee determination process. Unfortunately, the determination process often took longer than expected, thus requiring temporary settlement in transit area, in this case Indonesia. This is mainly the responsibility of Directorate General of Immigration, to distribute asylum seekers and refuges in available accommodations across Indonesia. However, most of these refugee 
accommodations come with negative implication: rumah detensi imigrasi (rudenim) or the detention center provided by the Indonesian immigration is operated like a jail. Asylum seekers often treated like a criminal, in this case illegal immigrant, which implied different consequences. Asylum seekers and refugees are protected by international laws and states have the responsibility to oblige. Meanwhile, illegal immigrant is not perceived as someone who needs protection but rather as someone who seeks better fortune despite the relative peaceful condition in his home country thus does not require (international) protection by other countries.

Nevertheless, it is worth our attention that Indonesia's overarching legal framework is actually rather "flexible", and thus provides a fluid foundation for refugee protection in Indonesia. Albeit restraining from the obligation to protect by never ratifying the 1951 Refugee Protection, Indonesia, under the Immigration Law, actually permits the temporary stay of asylum seekers and refugees in Indonesia. This temporary stay is allowed while waiting for their asylum request is being processed by UNHCR and or when they are granted asylum but still waiting for replacement in a third country.

Prior to the collaboration between IOM and JRS, most of asylum seekers and refugees would be relocated in rudenim all over Indonesia. The facility of rudenim was awfully below standard. Children has no access to education, women and men has no access to improve their skill and to get job. The general condition was then gradually improved, particularly for refugees, where they are now given the rights to stay outside the detention. Refugees now can stay inside local community temporarily, and detention center or rudenim are slowly transforming into better facilities through funding distributed by IOM and more educational and rehabilitation programs are delivered by JRS (interview with Stenger, 2014).

The humanitarian works, especially those on the efforts to accommodate and protect refugees and asylum seekers often went dry due to state's negligence. It is so, because at the end of the day, UNHCR as the leading agent cannot and may not interfere upon both transit country and third country decision to accept asylum seekers and refugees. The process of opening border for refugees and asylum seekers often practiced with political basis rather than humanitarian purposes. When working in humanitarianism, an involving state often brings a tendency that the humanitarian practice itself would lose its neutrality compass as Barnett claimed:

Humanitarianism was at its best when it stuck to the independent, neutral, and impartial provision of relief on victims of conflict and natural disasters, and began to lose its way and fall on hard times when it began to work alongside and with states, when it ventured away from symptoms to tackle the 'root causes' of suffering, and became involved in basic matters of governance. (Barnett, 2005)

Embarking from this argument and assuming that state's limitation in broader humanitarian context also valid for the international refugee regime; then relying solely on Indonesia's government initiative to move progressively on refugees issues, from non-signatory state to signatory state seems to be implausible. UNHCR describes that most of Southeast Asian countries are still reluctant to be signatory state of Refugee Convention. The reason to this varies for each country. However, at least for Indonesia, we could generally conclude that economic development is still the most important agenda for its government. Reducing national unemployment and poverty number are far more important than allocating more of its efforts on refugee and asylum seeker issues.

However, at the same time, it cannot be neglected that Indonesia is a strategic transit point for people who seek to enter Australia or seeking protection as refugee. Realizing these facts as two side of coins, slowly, Indonesia's government acknowledges that being part of international refugee regime is unavoidable, thus allowing international organizations and NGOs to take place in its region, whilst at the 
same time actively protect its border by widely ceased down the amount of illegal boat containing asylum seekers crossing the state's border and helping the asylum seeker registering process and refugee determination (and housing) by 2013 (Misbach, 2014). At the same time, this serves as justification of a state to help 'protecting' asylum seekers from human trafficking and when the status as refugee is granted, also ensuring the fulfillment of, at least, basic human rights.

Since state, in particular, opted out from signing refugee convention with the alternative of using the existing international refugee system, there is one remaining question: the average amount of time for asylum seekers to register, gain refugee status and settlement in third country often amounted up to one year and even more. This means refugees need to stay at the limited facilities of housing in Indonesia. On top of that, the number of asylum seeker coming to Indonesia keeps on raising significantly (UNHCR, 2014). Then, what are the alternative to this issue and to the raising number asylum seekers and refugees in Indonesia?

Although Indonesia is a non-signatory state of refugee's convention, its passive attitude towards refugee issues does not mean the issue is being abandoned. Indeed, refugee and asylum seeker issues are still taken care of through the inclusion of humanitarian values in international ethics thus allowing the institutionalization of international humanitarian regime through the involvement of not only one actor or aspect but many. Among these actors and aspects are IGO, NGOs and the state itself, working together with the structure of laws, norms and rules (Barnett, 2011). Continuing the discussion, we will shift our focus to the collaboration taken place in Indonesia between IOM, JRS and Directorate General of Immigration.

\section{Analysis on Non-State Actors: Sewon Community Center}

A Refugees community housing or community center is established to accommodate asylum seekers who have already been granted the status of refugees or whose status have been granted by the UNHCR and are being settled temporarily until permanent settlement in Australia. There are 42 community houses all around Indonesia, distributed in 6 provinces/cities; Sumatera Utara (Medan), Kep. Riau (Batam), DKI Jakarta, Jawa Timur (Surabaya), DIY (Bantul), Sulawesi Selatan (Makassar). All of these community houses are currently accommodating 2,599 refugees, asylum seekers, and other vulnerable migrants (data as of August 2014 by IOM).

The ultimate reason to carry out the research in community centers relates to our concern about the policies concerning and affecting refugees in Indonesia. As elaborated above, Indonesian government has been dealing with refugee protection issue passively. Compared to the border protection efforts reflected in the cooperation with neighboring countries, the 'protection', referring to attempts to meet the asylum seekers and refugees' rights, remain feeble. Given this situation, it is crucial to shift our attention from the 'top-down' policy to any endeavors arising from non-state actors, as one of many form of bottom-up initiatives.

If rudenim is established under the Directorate General of Immigration, Ministry of Law and Human Rights, then community houses initiatives were born from non-state actors. The main actor establishing the community housing program in Indonesia is International Organization for Migration (IOM) with the help of NGOs, i. e. Jesuit Refugee Service (JRS) and with coordination with the Immigration Offices. Community houses are managed in different ways from detention centers. Detention centers are almost like "jails", for they restrict asylum seekers and refugees' rights of movement and lock a huge number of them in one residence. Aside from the rights of movement, detention centers also undermine other rights of refugees as a human; rights to welfare and employment. In addition to that, detention centers are not safe for vulnerable groups, especially the children.

Community houses, on the other hand, do not restrict the rights of movement of the dwellers as they are 'made' mainly for refugees. It is established inside a local 
community (not separated from communities, as is the case of detention centers), with various levels of facilities. Some community houses are provided in forms of boarding house, some are hotels, and some are like rumah susun or apartment (IOM, 2014). Refugees obtain different "legal status" from asylum seekers, thus are entitled to rights of movement and capable to access public services in Indonesia, like market, public health services, and so on, although some limitations are inevitable due to their 'foreigner' status. The elaboration in the next part will explain the characters of the community houses in Indonesia, with a case study on Dinas Sosial Community House in Sewon, Bantul, Daerah Istimewa Yogyakarta.

The aim of this research is centering our attention to the attempts to perceiving refugees as part of global community. By learning how community houses work in Indonesia, we will be able to view how this perception is embedded in actions from NGOs, international organizations, neighboring community nearby the community houses, and even individuals from Indonesian government agency who are engaged in the management of the community house.

Since Indonesia has not ratified the 1951 Convention related to the Status of Refugees or the 1967 Protocol, the establishment of UNHCR offices becomes crucial for the efforts of basic rights fulfillment and settlement for the asylum seekers and refugees. Aside from not ratifying the convention, Indonesia, like many other South-East Asia countries, also does not have national legal framework or specific legal mechanism to deal with the issues of asylum seeker and refugees. Thus, to deal with these issues in Indonesia, the UNHCR adopt the procedures and criteria for determining refugee status under the 1951 Convention and the 1967 Protocol relating the status of refugee whilst at the same time working with two government bodies, Directorate General of Immigration Ministry of Foreign Affairs and Ministry of Law and Human Rights. In addition, UNHCR establishes cooperation with three main non-state actors i.e.
International Organization for Migration (IOM), Church World Service (CWS) and Je Suit Refugee Service (JRS) who provides basic necessities for the asylum seeker and refugees during their settlement process in Indonesia. To accommodate this collaboration and cooperation, UNHCR set up a branch office for registration and refugee status determination (RSD) in Jakarta, along with 12 other staff out-posted in seven locations of IOM's offices in Medan, Tanjung Pinang, Makassar, Kupang, Pontianak, and Surabaya.

Indonesia's location is crucially strategic for asylum seekers who would like to enter Australia as their new settlement. It has several critical entry points such as Batam for irregular migration especially from Afghanistan, Myanmar, Somalia, Sri Lanka, and Iran. As one of the main government bodies dealing with asylum seekers and refugees, the Directorate General of Immigration set up and manages detention centers spread out all over Indonesia. On its earliest stage, the detention centers for both asylum seekers and refugees feature minimum facilities that are often notoriously known as "a prison-like facility". Due to the crucial participation from IOM, the detention center facilities are progressively, if not quickly, transformed into better initiatives. For example, what once used to be Batam Immigration Detention Center now has been transformed into Sekupang Refugee Shelter, an apartment complex capable of housing 159 people.

Meanwhile in Yogyakarta, IOM who is collaborating with JRS, rent and transform a compound of housing owned by Social Service of Yogyakarta Province. The place often referred as Refugee Center Sewon or Wisma Refugee Sewon. Just like the detention center, refugees' presence in Yogyakarta is of responsibility of the Office of Immigration. However, the refugees remain as IOM's responsibility where IOM provides monthly allowance to each of the refugee registered in the center. On the other hand, JRS is entrusted to design two kinds of programs, they are "educational" programs that will provide basic skill such as computer and English and Indonesian skill, to the refugees, 
based on the refugee's request, until their settlement in third countries, and recreational programs, usually sport activities, i. e. futsal or visit to tourism objects. Briefly said, JRS is responsible for refugee's basic social and psychological recovery. Due to the limited funding, the programs are found to be limited, because based on the need assessment; some refugees also wish to obtain education on other skills, i. e. in farming or engineering (Interview with Stenger andSanjaya, 2014).

During their stay in Refugee Center Sewon, refugees are allowed to move inside Yogyakarta but are not allowed to go outside of Yogyakarta Province without supervision from IOM or JRS. A collective trip also requires permission from the Office of Immigration. Nevertheless, refugees can freely move and access all public facilities available in Yogyakarta Province similar to citizen of the province. In fact, refugees are also encouraged to socialize with the surrounding communities. In addition to the educational and recreational programs, JRS also initiates the socialization program aimed to foster integration or at the least raising awareness of the local communities and government about refugees. The routine activities include events held in Refugee Day annually, and sport activities with local youth (Interview withSanjaya, 2014). Unfortunately, this has not been an easy case. Although IOM and JRS have been working hard for the welfare of the refugees, especially as seen through JRS initiative to encourage interaction and communication with local communities, the efforts remain lacking due to several difficulties, such as language barriers between refugees and local communities. This is because the refugees prefer English to Indonesia, lacking of commitment from local entities (youth organization) to mediate the socialization and interaction between refugees and local community (Interview with Lakshana, 2014; Interview with Stenger and Sanjaya, 2014).

Learning from this role distribution, there is a clear distinction area of concern on each actor's participation to refugees issue. Indonesia government, here represented by the Office of Immigration as the main means to address refugees issue, acts as the extension of state to protect not only its geographical sovereignty but also the social sovereignty of its people. Thus, they act rather like a police who perceive refugees as criminal who broke the geographic borders as illegal immigrants who might threaten the social stability of the state. Within those perspectives, detention centers were established in the atmosphere of "a prison like facility". This is an indication of Indonesia's passive participation in asylum seekers and refugees issues, whereas being passive actor means limited exposure to asylum seekers and refugees understanding. It also leads to limited view and perceptions on rights of, especially, the refugees which somehow still perceived as illegal immigrants because status settlement are conducted by UNHCR officers instead of the Immigrations or any particular appointed government bodies for refugees.

On the other hand, IOM and JRS acted as non-state actors whose action and policy are not limited by the notion of "state", but compromise its participation to address refugee issues in Indonesia through role distribution. The two organizations also work hand in hand to shift state's approach towards asylum seekers and refugees. Refugee Centre in Sewon is one of the success stories of state's slowly shifting approach towards asylum seeker, instead of taking the form of detention. Nevertheless, state's participation in this shift remains relatively passive because the initiative comes from IOM, but there is a sign of progressive approach from state's perspective towards refugees welfare and rights by allowing new concept of refugee centers/shelters and on top of that the community housing as well, a humanize version of detention centers, although this does not necessarily means Indonesia willingness to sign the refugee's convention anytime soon.

\section{Conclusion}

IOM and JRS have done a crucial role whether it is through the assistance programs or the establishment of community housing itself. This answers our question about to what extent have these actors endorsed a new perspective about refugees. Therefore, the role 
of international organization in Indonesia becomes highly important to ensure that the most basic rights of asylum seekers and refugees which temporarily under Indonesia's government's territory could be fulfilled. The limited capacity of state to provide maximum accommodation and alternatives to detention has opened the gate for the non-state actor to play greater and bigger role in the field. It is true that non-state actor may have limited capacity and resources, but at least they provide solution for helping the state to manage the status determination and day-today assistance. Community housing appears as an alternative to detention centers and, together with educational and recreational programs, it creates a perspective that refugees obtain the same rights as citizens. However, it is important to recognize that this perspective still entails the notion of "outsider" attached to refugees and asylum seekers as community housing is only an alternative for refugees who received their status from UNHCR. Asylum seekers remain detained as illegal immigrants, confirming the grasp of their "outsider" status.

It is true that under the similar legal framework, the asylum seekers have been locked up in the rudenim all over Indonesia. However, it is also upon this foundation that the transformation of a humanized detention centers are possible to take place in the form of refugee shelters/centers and community housing; and at the same time also refugees may get their rights of movement and access to public services. The possible future directions can be an extension of the prevailing situation into a broader access to public service, i.e. vocational education.

The elaboration of the roles performed by IOM, JRS as well as the Department of Immigration in the previous section demonstrates the system of protection in Indonesia established from below and above. IOM as the ultimate actor in Sewon is the initiator who came up with the idea of providing alternative to detention centers. Aside from providing a more proper place for refugees, the community housing for refugees also signal the attempt to integrate the refugees with society. Despite the fact that most refugees stay only in a very short period of time in the community housing, the overall facilities and "freedom" provided for refugees, help them to interact with the local community. With the help of JRS as facilitator, which delivers a set of lessons, the refugees could catch up with the outside world and prepare themselves for future resettlement.

Herein, IOM and JRS played, although limitedly, the developmental role of non-state actors as explained in the initial part of this paper. In economic aspect, IOM contributed by providing the community housing and weekly allowance- assistances that are not provided by the state, in this case, Indonesian government. In social aspect, IOM and JRS both nurture the refugees through daily assistance and other programs, i. e. socialization program in the surrounding community. In the political aspect, the assistance from the non-state actors makes system rhetoric of refugee protection possible.

The political aspect of the community housing and the assistance given to refugees there can further be elaborated by looking into the extent the community housing has influenced the state's policy. From this initial research, it is found that Indonesian government, or in this case, the Office of Immigration agrees upon the freedom of movement of refugees within Indonesia. They are treated as no different from citizens at some aspects. Nevertheless, we need to see this as a limited freedom; although permitted to go outside their housing, they are still not allowed to leave the province during the period of waiting for resettlement. Nor can they obtain other extended rights, i. e. rights to obtain driving license or rights to get married (Lakshana, 2014).

Furthermore, the political aspect can be examined by paying closer attention to the rhetoric of refugees' rights being established in this assistance. As understood in the language of policy in Indonesia, in general, refugees are still regarded as people outside Indonesian citizenship system. Asylum seekers are detained in jail-like place and can only access to the community housing and some extent of freedom when UNHCR has 
decided that they are genuine refugees or when IOM and JRS granted their approval to help the asylum seeker. In summary, albeit showing developmental role in its program, we found the rhetoric about rights of asylum seekers as entitlement from the state instead of the rights inherent to the refugees. Consequently, any endeavor to assist refugees should conform to the national interest and immigration law.

As a matter of fact, there is still one remaining question of how to engage local community as the smallest derivative of "international civil society" and thus allowing more community housing and similar activities to flourish in Indonesia? JRS addresses this issue by pointing out the importance of local community's role to increase the number of community housing for refugees, thus raising the capacity and hopefully shortening the average length of waiting time. By local community involved, we meant that refugees could stay alongside with local community residency. IOM has been trying to cultivate this initiative in 42 community housings spread all around Indonesia. In this context, IOM and JRS have taken over the developmental role which supposed to be fulfilled by state-both the origin state of the refugee and Indonesia as the transit state-as part of the international refugee regime. On the tip of the iceberg, Indonesia as a state considers the current international refugee regime specifically working in Indonesia as enough to overcome asylum seekers and refugees temporarily stay in Indonesia. However, just like state has its limitation, non-state actors also has their own limitation usually comes from the aspect of funding and human resources.

Hence, humanitarian consciousness of local community in Indonesia should be encouraged. Local community should be aware that they are the smallest derivative of international society of an international refugee regime, which could also contribute, encourage and enforce new norms, alternatives, mechanisms, and methods objectively without losing its independence and neutrality. State, on the other hand, will be urged by this bottom-up initiative, leaving it no other option to cater its people'a concern.

\section{Bibliography}

\section{Books}

Benhabib, S. (2006). The Philosophical Foundations of Cosmopolitan Norms. In Benhabib, S. (Ed.). Another Cosmopolitanism (pp. 13-44). New York: Oxford University Press.

Betts, Alexander and Gil Loescher (eds). (2011) Refugees in International Relations. Oxford: Oxford University Press.

Derrida, J. (2001). On Cosmopolitanism and On Forgiveness. London: Routledge.

Edwards, M. (2009). Civil society. Cambridge: Polity.

Edwards, M., \& Hulme, D. (Eds.). (1995). Non-governmental organisations: performance and accountability beyond the magic bullet. London: Earthscan.

Goodwin-Gill, G. (1996). The Refugee in International Law. (2nd edn.). Oxford: Clarendon Press.

Glick-Schiller, N. (2010). A Global Perspective on Transnational Migration: Theorizing Migration without Methodological Nationalism. In Bauböck, R. and Faist, T. (Eds). Diaspora and Transnationalism: Concepts, Theories and Methods. Amsterdam: Amsterdam University Press.

Hammerstad, A. (2014) The Rise and Decline of A Global Security Actor: UNHCR, Refugee Protection, and Security. Oxford: Oxford University Press.

Kusumaatmadja, M. (1983) Politik Luar Negeri Indonesia dan Pelaksanaannya Dewasa Ini. (eds.: Eddy Damian and Budiono Kusumohamidjojo). Bandung: Penerbit Alumni.

McNevin, A. (2011). Contesting Citizenship: Irregular Migrants and New Frontier of Political. New York: Columbia University Press.

Però, D. (2011). Migrants' Practices of Citizenship and Policy Change. In 
Shore, C. Wright, S. and Però, D. (Eds.). Policy Worlds: Anthropology and Analysis of Contemporary Power (pp. 244-263). Oxford: Berghahn.

Warner, D. (1999). The Refugee State and State Protection. In Nicholson, Frances and Patrick Twomey (eds.), Refugee Rights and Realities: Evolving International Concepts and Regimes. New York: Cambridge University Press.

\section{Journals, Newsletter \& Reports}

Helton, A. (2002). The price of indifference. The Price of Indifference.

Mathew, P. \& Harley, T. (The Australian National University) (2014, March) Refugee Protection and Regional Cooperation in Southeast Asia: A Fieldwork Report).

IOM Indonesia. (IOM Indonesia Newsletter, Issue 4). (September 2014) Alternatives to Detention IOM Indonesia.

Nyers, P. (2003). Abject cosmopolitanism: the politics of protection in the antideportation movement. Third world quarterly, 24(6), 1069-1093.

\section{Online Articles}

Missbach, A. (2014) Refugees Lost In Transit In Indonesia [Online]. Available from: https://newmatilda.com/2014/o 4/o7/refugees-lost-transit-indonesia [Accessed on 2 November 2014].

The Jakarta Post. (2011) Indonesia hosting close to 3,Ooo refugees: UNHCR [Online](2011) Available from: http://www.thejakartapost.com/news/ 2011/06/21/indonesia-hosting-close3000-refugees-unhcr.html [Accessed on 2 November 2014].

UNHCR. (2014) 2014 UNHCR Regional Operations Profile - Southeast Asia [Online]. Available from http://www.unhcr.org/pages/49e48811 6.html [Accessed on 2 November 2014].

UNHCR. (2014) What We Do: Durable Solutions [Online]. Available from: http://www.unhcr.org/pages/49c3646c f8.html [Accessed on 2 November 2014].

\section{Interview}

Interview with Lars Stenger (Jesuit Refugee Service), October 72014.

Interview with Lino Sanjaya (Jesuit Refugee Service), October 7, 2014.

Interview with Raden Dyka Lakshana (Kepala Sub Seksi Pengawasan Keimigrasian), Kantor Imigrasi Yogyakarta, October 7, 2014. 
